\title{
Prevalence of Cervical Intra Epithelial Neoplasia (CIN) among the sexually active married Women at Rajshahi Division
}

\author{
JESMIN SHAHELA ${ }^{1}$, NAJNIN MONIRA ${ }^{2}$, ASHRAFUNNESA $^{3}$, AFROZ ROMANA $^{4}$, \\ SARKAR MOUSUMI ${ }^{5}$, SHAMIMA NARGIS ${ }^{6}$,
}

\begin{abstract}
:
Background: Cervical cancer is $4^{\text {th }}$ most common cancer in women in the world and the most common form of cancer in women in developing countries. Population based cervical cancer screening and treatment of intraepitheial neoplasia in early stage can reduce morbidity and mortality associated with cervical cancer.

To determine the prevalence of cervical intra epithelial neoplasia (CIN) among sexually active and married women in Rajshahi Division of Bangladesh.

Place and Duration: This population based cross sectional study was carried out in 4 selected Upazilla from 4 different districts of Rajshahi Division from $1^{\text {st }}$ December 2014 to $31^{\text {st }}$ May 2015. Study on 1050 sexually active women between 25 to 55 years of age who fulfilled the inclusion criteria enrolled in the study after taking the consent.

Result: Among 1050 enrolled women 90 (8.5\%) were VIA positive and 91 were colposcopically abnormal and among them 33 were CIN positive \& 58 had chronic cervictis with or without squamorus metaplasia.

Mean age of CIN positive women was 36.75 years, $92.2 \%$ were housewife $\& 7.8 \%$ were service holder and in $64.6 \%$ women education level was up to XII class. In fifty five percent of their husband was day labouer from poor socioeconomic condition.

Conclusion: VIA and Colopscopy can differentiate a normal cervix from a precancerous cervix with reasonable accuracy. Till now a good number of studies had been carried out in different countries of world and it is now well established that sensitivity of the test is very good. From the present study we can conclude that it will give a very good information about the prevalence of CIN in our country and by proper management of the CIN cases the incidence of carcinoma cervix can be reduced.
\end{abstract}

Key Words: Cervical Intra epithelial Neoplasia (CIN), cervical cancer screening.

Introduction:

Cervical cancer is $4^{\text {th }}$ most common cancer in women in the world and the most common form of cancer in women in developing countries. ${ }^{1}$ This situation is compounded by the fact that in under developed countries $75 \%$ of affected women present in advanced stage, which is in contrast to developed countries where $75 \%$ patient present in early stage and a cure can be expected. It is estimated that up to 500,000 new cases of invasive cancer of the cervix

1. Professor \& Head of the Dept. of Obs\&Gynae, Rajshahi Medical College.

2. Junior Consultant (Obs\&Gynae) Upazilla Health Complex, Gomostapur, Chapai Nawabgonj.

3. Gynaeoncology (Obs\&Gynae), BSMMU.

4. Colposcopist, BSMMU.

5. Indoor Medical Officer (Obs\&Gynae) RMCH.

6. Assistant Prof. (Obs\&Gynae) RMC.

Address of Correspondence: Dr. Shahela Jesmin, Professor \& Head, Department Obstretics \& Gynaecology, Rajshahi Medical College Rajshahi, Bangladesh. Email: shahelajessmin@gmail.com 
occur per year worldwide, leading to 273000 deaths $\& 80 \%$ of these occur in under developed countries. ${ }^{2}$

It is one of few malignancies in which premalignant condition exist and effective cytological screening method is available. Population based cervical cancer screening and treatment of intraepitheial neoplasia in early stage can reduce morbidity and mortality associated with cervical cancer. ${ }^{3}$ It is recommended that all sexually active women between ages 20-60 years should have cervical screening every three years as it detect premalignant condition. ${ }^{5}$ However discovery of Human papilloma virus (HPV) as a necessary factor for developing cervical cancer has led to introduction of HPV DNA testing and HPV vaccination which may improve the outcome of cervical cancer prevention. ${ }^{4}$

In Bangladesh incidence of cervical cancer is about 17,686 and around 10,364 women die from cervical cancer each year. In 2012, it was estimated that there were 528,000 cases of cervical cancer and 266,000 deaths.

Invasive squamous cell cervical cancer are usually preceded by a long phase of pre-invasive disease, collectively referred to as cervical intra-epithelial neoplasia. CIN is not cancer and $99 \%$ of which are curable. Most cases of $\mathrm{CIN}$ remain stable or eliminated by host's immune system without intervention. However, a small percentage of $\mathrm{CIN}$ cases progress to become cervical cancer if left untreated.

Majority of cervical cancers in united states occur in women who have never been screened within past five years, additional cases occur in women who do not receive appropriate follow up after an abnormal pap smear. ${ }^{6}$ In England and Wales incidence of cervical cancer fell by 42\% between 1988 and 1997 . This is directly related to effective cancer cervical screening programme. ${ }^{7}$

\section{Patient \& Method:}

It was a cross sectional study, done in four upazillas under four districts of Rajshahi division. Total 1050 women were recruited in this study over a period of six (6) months from December'14 to May'15. The selected Upazillas were: Atghoria of Pabna, Puthia of Rajshahi, Lalpur of Natore, Shibganj of Chapainawabganj.

The study was conducted through a research team of Rajshahi Medical College Hospital and UHC. The team composed of (1) Principal investigator (2) Co- investigator (3) Colpscopists (4) Research Assistant (5) Co-Ordinator (6) 3 Nurses (7) Field staffs (Health Assisstent-4) (8) Ayas (2).

There was one day training in each Upazilla Health Complex (UHC) for selecting the participants from households of each union of the selected upazillas. The target population were \& married women aged 25-55 years who were apparently healthy, ambulant and gave consent to participates in the study.

Study population were selected following inclusion and exclusion criteria then a research assistant counseled and explained about the study to each selected women and took a written informed consent. In Lithotomy position, cervix was exposed by Cusco's vaginal speculum. Any evidence of infection, ectopy, polyps, leukoplakia, growth etc. were checked. Then VIA and Colposcopy were performed simultaneously. All colposcopically suspected CIN cases had punch biopsy. Specimens were sent for histopathology to the pathology Department of BSMMU. All the result were documented in standard questionnair form.

Then sociodemographic data was analyzed in frequencies and percentage. Frequencies of $\mathrm{CIN}$ at 4 upazilla also analyzed.

\section{Results:}

A total 1050 cases were enrolled and evaluated regarding their socio demographic profile, colposcopic findings and histological reports. The age range of the study group was between 25 to 55 years. And mean age was 36.75 years. The maximum women $(81.6 \%)$ were between $30-44$ years of age. Among 1050 study cases about $92.2 \%$ were housewives and $7.8 \%$ were service holders. About $65 \%$ women had education level up to class XII; $27 \%$ were illiterate and $8.4 \%$ were graduate. Their husbands were; day labour $55.5 \%$ \& in $48.6 \%$ education up to class XII. Their income was up to $15,000 /$ - per month in $85.0 \%$ cases. Age of marriage was $15-19$ years in $57.4 \%$ of the patient. Age of first delivery $15-19$ years in- $51.2 \%$ and $20-24$ years in $33.2 \%$ cases.

Single marriage was in $95.4 \%$ cases; regarding parity- 2 child about $45.4 \%$ cases $3+$ child about $36.3 \%$ cases; $94 \%$ couple used to live together. 


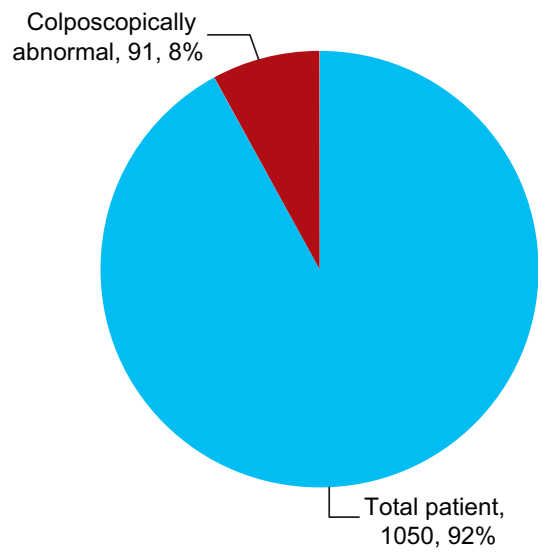

Fig.-1: Distribution of study subjects accordingly to findings of colposcopic examination $(n=1050)$

Figure-1 shows: out of 1050 women screened 960 $(91 / 4 \%)$ were VIA negative yielded normal colposcopic findings in 959 (91.3\%). In 90 (8.6\%) VIA test was positive and colposcopic abnormalities were seen in 91 (8.7\%) cases.

Out of 91 women who had colposcopic abnormalities histopathology report showed that of seven positive women in Figure-2.

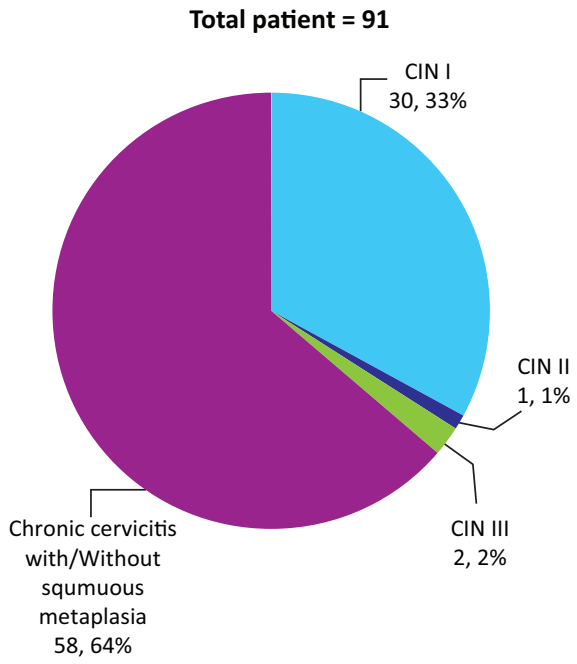

Fig.-2: Distribution of colposcopic positive women according to histopathological findings $(n=91)$

Figure-2 shows: CIN-I was found in $30(2.9 \%)$, CIN-II in 1 patient $(\cdot 1 \%), \mathrm{CIN}-\mathrm{III}$ in 2 patient $(\cdot 2 \%)$, chronic cervicitis with / without squamous metaplasia in58 patient $(4.57 \%)$.

Out of these 33 patient (who has CIN) 15 (45\%) patient come for LEEP and we had done LEEP for those patient and tissue was sent for histopathology and report shows:
- $\mathrm{CIN}-\mathrm{I}$ in 4 patient out of 1050 women ( $4 \%$ ).

- CIN-III in 1 patient ( $1 \%)$.

- Chronic cervicitis in 10 (.95\%) patients.

\section{Disecussion:}

Cervical cancer is the $4^{\text {th }}$ most cancer in woman world wide, with an incidence varies from 10 per one lac woman in industrialized countries to 60 per one lac in some developing countries. ${ }^{8}$

In USA about 250,000 to one Million women develop $\mathrm{CIN}$ amunally. CIN can develop at any age, however woman generally develop it between the ages of 2535 years. But in our study vulnerable ages between 30-44 years \& mean age is 36.75 years. Another study by Khustagi \& Fernands showed prevalence of CIN was higher in woman over age 30 years. ${ }^{9}$

In our country common people have scarce knowledge and information about cervical cancer and its risk factors. Illiteracy is one of the important risk factor because it affects woman nutritional status, perineal hygiene, age of marriage, parity, contraceptive choice and health seeking behavior. In our study $27 \%$ patient were illiterate.

Age at first coitus is one of the important eitilogic factor of cervical cancer. In our study age of marriage from $15-19$ years in about $57.4 \%$ women which is higher in comparison to one study in pakistan.

Risk factors for cervical cancer are early sexual exposure, multiple sexual partner, non use of condom, cigarette smoking, HPV infection, use of oral contraceptives, low socioeconomic status \& high parity. ${ }^{11}$

Male circumcision thought to protect woman from the development of cervical cancer because only $5.5 \%$ of circumcised men harbor HPV in comparison with $19.6 \%$ uncircumcised men. ${ }^{12}$

An international study collect specimen from 32 Hospital in 22 countries proved that HPV DNA was present in $99.7 \%$ of cervical cancer. HPV 16 was predominant.

Limitation of the study were HPV-DNA testing was not done due to lack of our technical support; and LEEP could not be done in all CIN positive women because they did not report for LEEP.

\section{Conclusion:}

From this study we get information about the prevalence of CIN in Rajshahi Division. Inspite of this 
information there were some limitation that we could not collect endocervical curettage on scraping which is necessary for detectation of endocervical cancer and we have no support for HPV DNA testing.

To know the prevalence, effective screening programme should be launched at national level and awareness must be created in health care providers and care seekers regarding screening of cervical cancer.

\section{References:}

1. Pierre L, Hirsh M. Cervial cancer. An evidence based test for MRCOG.Seed.London: Arnold. 2010:808-13.

2. Mahmood S, Premalignant and malignant diseases of cervix, Dewhuersts: 614 .

3. Gichangi P, Estamble B, Bwayo J, Ogo K, Ojwang S, Opiyo A, et. al. Knowledge and practice about cervical cancer and pap smear testing among patients at Kenyatta national hospital Narobi, Kenya. Int J gynecol cancer 2003;13: 827-33.

4. Greenlee RT, Murray T, Bolden,et.al: cancer studies,2000,Ca-a cancer journal for clinicians 2000;50(1);7-88.

5. Sharma M, Ortendahl J, Van der Ham E,Sy S, Kim J. Cost effectiveness of human papilloma virus vaccination and cervical cancer screening in Thiland. BJOG 2012;119:166-176.

6. Hildesheim A, Hadjimichael O, Sehwartz PE, et al. Risk factor for Rapid onset cervical cancer. Am J Obstet Gynecol.1999;180(3 pt 1):571-7.

7. Quinn M, Babb P, Jones J,et al. Effect of screening on incidence of and mortality from cancer of cervix in England: evolution based on routinely collected statisties. BMJb1999; 318:904-8.

8. Juneja A, Sehgal A, Mitra AB, Pandey A. Survey on rosk factors associated with cervical cancer. Indian J cancer. 2003 Jan-march;40 (1):15-20.

9. SaraiyaUB. Cancer screening in Gynaecology, In Ratnamss, RaoKb\&Arulkumarans, editor, obstreties and Gynaecology, orient Longman, India 2004.2:454-464.

10. Ahmad N, Mehbood R. Cervical intra-epithelial neoplasia recent trend in diagnosis and management Pak journal Med Res Apr-Jun 2002;41(2):43-5.

11. Khan MS, Raja FY, Ishfaq G. Tahir F, Subhan $F$, Kazi BM et al. Pap screening for precancerous conditions of cervical cancer. Pak J Med Res Jul-Sep 2005; 4493): 111-3. 